\title{
FORMULASI DAN EVALUASI FISIK SALEP ANTI JERAWAT EKSTRAK ETANOL 96\% DAUN PEPAYA (Carica papaya L.) TERHADAP BAKTERI Propionibacterium acnes
}

\section{FORMULATION AND PHYSICAL EVALUATION OF ANTI ACNE ETHANOL EXTRACT 96\% PAPAYA LEAF (Carica papaya L.) ON BACTERIA Propionibacterium acnes}

\author{
Rahmawida Putri ${ }^{1 *}$, Riki Hardiansah ${ }^{1}$, Jaka Supriyanta ${ }^{1}$ \\ ${ }^{1}$ Sekolah Tinggi Farmasi Muhammadiyah Tangerang \\ ${ }^{*}$ Corresponding Author Email: rahmawidaputri0@gmail.com \\ DOI: http://dx.doi.org/10.47653/farm.v7i2.208
}

\begin{abstract}
ABSTRAK
Ekstrak etanol $96 \%$ daun pepaya (Carica papaya L.) memiliki aktivitas farmokologi sebagai antibakteri, antelmintik, antimalaria dan antiinflamasi. Aktivitas tersebut diduga disebabkan kandungan kimia yang terdapat di dalam ekstrak. Salah satu senyawa aktif yang terdapat pada ekstrak daun pepaya adalah alkaloid karpain yang memiliki aktivitas sebagai antibakteri. Penelitian ini bertujuan untuk mengetahui sifat fisik sediaan salep dan pada konsentrasi berapakah sediaan salep ekstrak etanol $96 \%$ daun pepaya (Carica papaya L.) mempunyai aktivitas yang paling optimal terhadap bakteri Propionibacterium acnes. Jenis penelitian ini yaitu penelitian secara eksperimental dengan analisis secara deskriptif. Pembuatan ekstrak daun pepaya dilakukan dengan metode maserasi, yang kemudian digunakan sebagai zat aktif pada sediaan salep antijerawat dengan konsentrasi FI 5\%, FII 10\% dan FIII 20\%. Hasil penelitian menunjukkan sediaan salep antijerawat ekstrak etanol $96 \%$ daun pepaya mempunyai sifat fisik yang baik, dan hasil pengujian antibakteri tidak memberikan efek penghambatan terhadap bakteri Propionibacterium acnes dikarenakan konsentrasi ekstrak terlalu rendah.
\end{abstract}

Kata Kunci: Ekstrak Daun Pepaya, Salep Antijerawat, Sediaan Salep, Propionibacterium acnes

\section{ABSTRACT}

Ethanol extract $96 \%$ papaya leaves (Carica papaya L.) has pharmocological activity as antibacterial, anthelmintic, antimalarial and anti-inflammatory. The activity is thought to be due to the chemical content contained in the extract. One of the active compounds contained in papaya leaf extract is a carpain alkaloid which has antibacterial activity. This study aims to determine the physical properties of ointment preparations and at what concentrations ointment $96 \%$ papaya leaf extract (Carica papaya L.) has the most optimal activity against Propionibacterium acnes bacteria. This type of research is experimental research with descriptive analysis. Making papaya leaf extract is done by maceration method, which is then used as an active ingredient in preparations of anti-acne ointments with concentrations of $\mathrm{FI} 5 \%$, FII 10\% and FIII 20\%. The results showed that anti-acne ointment $96 \%$ papaya leaves had good physical properties, and the results of antibacterial testing did not provide any inhibitory effect on Propionibacterium acnes because the extract concentration was too low.

Keywords: Papaya Leaf Extract, Anti-acne Ointment, Propionibacterium acnes

\section{PENDAHULUAN}

Salah satu tanaman dan tumbuhan yang dapat dimanfaatkan untuk menyembuhkan penyakit kulit (jerawat) adalah menggunakan daun pepaya (Carica papaya L.) dengan harga yang murah dan mudah didapat, diharapkan dapat digunakan untuk mengobati jerawat. Karpain yang terkandung dalam daun pepaya (Carica papaya L.) mempunyai efek sebagai antimikroba (Peristiowati dkk, 2018).
Jerawat merupakan salah satu penyakit kulit yang disebabkan karena terjadinya penyumbatan kelenjar minyak pada kulit yang disertai infeksi dan peradangan. Jerawat umumnya muncul pada wajah, tetapi dapat juga muncul pada daerah selain wajah, tetapi dapat Juga muncul pada daerah kepala, punggung, dada, atau lengan atas (Sawarkar,dkk. 2010). 
Sediaan salep merupakan bentuk sediaan yang memiliki konsistensi yang cocok digunakan untuk terapi penyakit kulit yang disebabkan oleh bakteri (Pasroni dkk, 2004). PEG 400 dan PEG 4000 dipilih karena tidak mengandung bahan berlemak, sehingga baik untuk sediaan antijerawat. Di karenakan bahan berlemak dapat memicu timbul nya jerawat (Yulistia dkk, 2016).

Berdasarkan hasil penelitian yang telah dilakukan oleh Fitria pada tahun 2015 dengan judul "Uji Aktivitas Antibakteri Ekstrak Etanol Daun Pepaya (Carica papaya L.) Terhadap Propionibacterium acnes" Hasil penelitian menunjukan bahwa ekstrak daun pepaya (Carica papaya L.) dapat menghambat pertumbuhan bakteri Propionibacterium acnes pada konsentrasi ekstrak $20 \%$ dengan diameter hambat paling optimal yaitu $19 \mathrm{~mm}$. Selanjutnya penelitian yang telah dilakukan oleh Syarifah, Reny dkk pada tahun 2015 dengan judul "Formulasi Sediaan Masker Gel Peel-Off Ekstrak Daun Pepaya (Carica papaya L.) sebagai Anti Jerawat dan Uji Aktivitasnya terhadap Bakteri Propionibacterium acnes". Hasil penelitian menunjukan bahwa Masker $\mathrm{Gel}$ Peel Off Ekstrak Daun Pepaya (Carica papaya L.) memiliki aktivitas antibakteri terhadap Propionibacterium acnes dengan diameter hambat sebesar $6,5 \pm 0,07$.

\section{METODE PENELITIAN}

\section{Alat}

Alat-alat yang digunakan dalam penelitian yaitu kertas saring, beaker glass $50 \mathrm{~mL}$ (Pyrex® IWAKI, Japan), $250 \mathrm{~mL}$ (Approx®), labu ukur 50 $\mathrm{mL}$ (Pyrex® IWAKI, Japan), corong, gelas ukur $100 \mathrm{~mL}$ (Pyrex® IWAKI, Japan), mortar, stamper, Bunsen, kaki tiga, batang pengaduk, kaca preparat, cawan petri, cawan penguap, viscometer (Lamy Rheology, Francis).

\section{Bahan}

Bahan-bahan yang digunakan dalam penelitian adalah Daun pepaya, PEG 400, PEG 4000 , nipagin, etanol $96 \%$, aquadest dan minyak jeruk.

\section{ALUR PENELITIAN}

\section{Determinasi Tanaman}

Determinasi daun pepaya dilakukan di herbarium bogoriens, Bidang Botani Pusat Penelitian dan Pengembangan Biologi-LIPI Cibinong, untuk memastikan kebenaran simplisia yang digunakan.

\section{Preparasi Sampel}

Daun pepaya (Carica papaya L.) yang telah didapat dibersihkan dengan menggunakan air kemudian dipotong-potong. Potongan daun pepaya dikeringkan dengan cara diangin-anginkan, kemudian dikeringkan dengan menggunakan oven pada suhu $50^{\circ} \mathrm{C}$, daun pepaya yang sudah kering diblender sampai berbentuk serbuk kemudian diayak menggunakan mesh No. 40. Lalu selanjutnya dilakukan uji parameter simplisia yakni :

a) Susut Pengeringan

1 gram sampel dimasukkan kedalam krus porselin yang sebelumnya telah dipanaskan pada suhu $105^{\circ} \mathrm{C}$ selama 30 menit dan telah ditara. Krus dimasukkan ke dalam oven dalam keadaan terbuka, keringkamn pada suhu $105^{\circ} \mathrm{C}$ hingga bobot tetap, dinginkan dalam eksikator dan replikasi sebanyak tiga kali.

b) Kadar Air

0,5 gram sampel ditimbang dan dimasukkan kedalam alat karl fischer kemudian didapatkan hasilnya.

c) Kadar Abu

Konstanta cawan kosong pada tanur suhu $\pm 550^{\circ} \mathrm{C}$ selama 5 jam. Timbang \pm 2 3 gram sampel menggunakan cawan konstan. Panaskan sampel di atas hotplate suhu rendah hingga abu sampel hilang. Masukkan sampel ke dalam tanur suhu $\pm 550^{\circ} \mathrm{C}$ selama 5 jam lalu timbang sampel yang sudah konstan (ulangi pengabuan bila nilai belum konstan).

\section{Pembuatan Ekstrak}

Proses ektraksi dilakukan dengan menggunakan metode maserasi menggunakan pelarut etanol $96 \%$. Maserasi dilakukan dengan perbandingan 1:10 yaitu sebanyak 1.000 gram serbuk simplisia direndam dengan pelarut sebanyak 10.000 $\mathrm{ml}$.

a) Skrining Fitokimia

Menurut (Handayani dkk, 2017) skrining fitokimia ini meliputi :

Identifikasi Alkaloid

Sebanyak 2 gram serbuk simplisia dibasahi dengan $5 \mathrm{ml}$ ammonia dan digerus dalam mortar. Tambahkan $20 \mathrm{ml}$ kloroform kedalam mortar dan gerus kuatkuat. Campuran disaring, filtrat yang diperoleh ditetesi pada kertas saring dan diberi beberapa tetes reagen Dragendorf. 
Reaksi positif ditandai dengan pembentukan warna merah atau jingga. Sisa filtrat diekstraksi dengan asam klorid 10\% (1:2) dan fraksi asam diambil dan dimasukkan dalam tabung rekasi lalu ditetesi pereaksi Mayer dan reaksi positif ditunjukkan dengan terbentuknya endapan putih.

Identifikasi Tanin

Ekstrak cair dimasukkan ke dalam tabung reaksi dengan masing-masing $3 \mathrm{ml}$ ekstrak. Tabung pertama ditetesi larutan $\mathrm{Fecl}_{3} 10 \%$. Hasil positif senyawa fenol ditunjukan dengan terbentuknya warna hijau, biru, atau hitam. Tabung kedua ditetesi larutan gelatin 1\%. Hasil positif tanin ditunjukkan dengan pembentukan endapan putih. Tabung ketiga ditetesi pereaksi steasny. Hasil positif tanin katekat ditunjukkan dengan pembentukan endapan merah. Campuran dari tabung ketiga disaring dan filtratnya ditambahkan natrium asetat hingga jenuh. Filtrate kemudian ditetesi larutan $\mathrm{FeCl}_{3} 10 \%$. Hasil positif tanin galat ditunjukkan dengan perubahan warna menjadi biru tinta.

Identifikasi Saponin

Sebanyak $10 \mathrm{ml}$ ekstrak cair dikocok vertikal selama 10 detik dan dibiarkan selama 10 menit. Hasil positif ditunjukkan dengan terbentuknya busa yang mantap selama 10 menit dengan tinggi $1-10 \mathrm{~cm}$. Kemudian tambahkan beberapa tetes asam klorida $2 \mathrm{~N}$. hasil positif ditunjukkan dengan busa yang tetap stabil.

Identifikasi Steroid dan Triterpenoid

Sebanyak 1 gram serbuk simplisia dimaserasi dengan $20 \mathrm{ml}$ eter selama 2 jam. Hasil maserasi kemudian disaring dan filtrat diuapkan. Kedalam residu diteteskan pereaksi Lieberman-Burchard. Hasil positif steroid dan triterpenoid ditunjukkan dengan pembentukan warna biru hijau atau merah ungu.

b) Pengujian parameter non spesifik ekstrak Kadar air

Sebanyak 0,5 gram sampel ditimbang, dimasukkan kedalam alat Karl Fischer kemudian didapatkan hasilnya.

Kadar abu

Konstanta cawan kosong pada tanur suhu $\pm 550^{\circ} \mathrm{C}$ selama 5 jam. Timbang \pm 2 3 gram sampel menggunakan cawan konstan. Panaskan sampel di atas hotplate suhu rendah hingga abu sampel hilang. Masukkan sampel ke dalam tanur suhu $\pm 550^{\circ} \mathrm{C}$ selama 5 jam lalu timbang sampel yang sudah konstan.

Sisa pelarut

1 gram ekstrak kental dilarutkan dengan $10 \mathrm{ml}$ aquadest. Hasil ekstraksi disaring disaring kemudian disuntikan sebanyak $1 \mu$ pada alat kromatografi gas.

Tabel 1. Formulasi Sediaan Salep

\begin{tabular}{|c|c|c|c|c|c|c|}
\hline Nama ba & & FI & FII & FIII & Kontrol (-) & Kegunaan \\
\hline $\begin{array}{l}\text { Ekstrak } \\
\text { Pepava }\end{array}$ & Daun & $5 \%$ & $10 \%$ & $20 \%$ & - & Bahan aktif \\
\hline PEG 400 & & 57,75 & 57,75 & 57,75 & 57,75 & Basis salep \\
\hline PEG 4000 & & 24,75 & 24,75 & 24,75 & 24,75 & Basis salep \\
\hline Nipagin & & 0,18 & 0,18 & 0,18 & 0,18 & Zat pengawet \\
\hline Oleum Citri & & qs & qs & qs & qs & Zat tambahan \\
\hline
\end{tabular}

\section{Pembuatan Salep Ekstrak Daun Pepaya}

a) Pembuatan Salep

Salep dibuat dengan cara melarutkan nipagin kedalam PEG-400. Kemudian meleburkan PEG-4000 kedalam campuran 1 diaduk sampai dingin. Menambahkan ekstrak daun pepaya kedalam campuran 2 lalu diaduk sampai homogen. Menambahkan oleum citri sedikit demi sedikit dalam campuran 3 . b) Uji Evaluasi Salep

Uji organoleptis

Pengujian dilakukan dengan cara mengamati tekstur, bau dan warna secara visual (Naibaho dkk., 2013).

\section{Uji Homogenitas}

Sebanyak 0,1 gram salep dioleskan di atas kaca objek atau sekeping kaca 
kemudian diamati apakah terbentuk partikel kasar atau tidak secara visual (Naibaho dkk., 2013).

\section{Uji pH}

Sebanyak 0,5 gram sampel diencerkan dengan $5 \mathrm{ml}$ air suling, kemudian celupkan kertas $\mathrm{pH}$ selama 1 menit. Perubahan warna yang terjadi pada kertas $\mathrm{pH}$ universal menunjukkan nilai $\mathrm{pH}$ pada salep (Yulistia B dkk., 2016).

\section{Uji Daya Sebar}

Sebanyak 0,5 gram sampel diletakkan diatas plat kaca, biarkan 1 menit dan ukur diameter sebar salep, kemudian ditambah dengan beban tambahan 200 gram dan didiamkan selama 1 menit, lalu ukur diameter sebarnya. (Yulistia B dkk., 2016).

\section{Uji Daya Lekat}

Sebanyak 0,25 gram sampel diletakkan diatas gelas obyek yang telah ditentukan luasnya, lalu ditekan gelas obyek yang lain diatas salep tersebut dan ditekan dengan beban 200 gram selama 5 menit. Kemudian dipasang alat pada gelas obyek dan catat waktu hingga kedua gelas obyek tersebut terlepas (Yulistia B dkk., 2016).

\section{Uji Vikositas}

Pengukuran viskositas dilakukan menggunakan alat First Touch Viscometer (Lamy Rheology) serial No : 17.07.TF 132. Voltage : 24 VDC Power : $60 \mathrm{~W}$, Frequencyn : $50 / 60 \mathrm{~Hz}$. Pengukuran viskositas salep dilakukan menggunakan spindle L No. 4, dengan durasi 60 detik dan dengan kecepatan $60 \mathrm{rpm}$.

\section{Pengujian Antibakeri}

a) Alat-alat yang akan digunakan pada uji aktivitas antibakteri terlebih dahulu dicuci bersih kemudian dikeringkan dan disterilisasikan dalam autoklaf pada suhu $121^{\circ} \mathrm{C}$ selama 15 menit.

b) Inokulasi Bakteri Propionibacterium acnes dan Uji Angka Lempeng Total.

1) Buatlah media Blood Agar sebanyak $20 \mathrm{ml}$ kemudian tuangkan pada cawan petri dan ambil bakteri dari ampul sebanyak 0,1 $\mu$ l kemudian masukkan kedalam cawan petri yang sudah terdapat media Blood Agar. Setelah itu inkubasi selama 48 jam dengan suhu $36^{\circ} \mathrm{C}$.

2) Buatlah media $\mathrm{BHI}$ sebanyak $20 \mathrm{ml}$ dan masukkan kedalam Erlenmeyer. Ambil Propioniacterium acnes diatas sebanyak 2 ose dan masukkan pada media $\mathrm{BHI}$ yang telah dibuat. Diaduk hingga merata kemudian diinkubasi selama 24 jam dengan suhu $36^{\circ} \mathrm{C}$ (Propionibacterium acnes pengenceran $10^{\circ}$ ).

3) Pipet $1 \mathrm{ml}$ sampel Propionibcterium acnes dan masukkan kedalam tabung reaksi yang telah berisi $9 \mathrm{ml}$ air fisiologis, goyangkan campuran hingga homogen (pengenceran $10^{-1}$, lakukan pengenceran hingga tingkat $10^{-7}$ ).

4) Pipet masing-masing $1 \mathrm{ml}$ dari pengenceran $10^{-5}-10^{-7}$ kedalam cawan petri steril secara duplo.

5) Kedalam setiap cawan petri tuangkan sebnyak $20 \mathrm{ml}$ sediaan Blood Agar yang telah dicairkan dari pengenceran $10^{-5}-10^{-7}$. Goyangkan cawan petri dengan hati-hati hingga merata.

6) Biarkan hingga campuran dalam cawan petri membeku, dan inkubasi pada suhu $36^{\circ} \mathrm{C}$ selama 72 jam.

7) Hitung dan atat pertumbuhan koloni pada setiap cawan petri yang mengandung 10-300 koloni. Serta hitung angka lempeng totalnya (SOP, Lab. Pengujian BP Bioteknologi, BPPT).

\section{Pembuatan Media Mueller Hinton Agar (MHA)}

Serbuk MHA sebanyak 2,28 gram dilarutkan dalam $60 \mathrm{ml}$ aquadest, kemudian dipanaskan sampai mendidih dan diaduk dengan vortex stirrer sehingga semuanya larut dan warna menjadi kuning bening.

\section{Pengujian Antibakteri}

Pengujian sediaan terhadap pertumbuhan bakteri Propionibacterium acnes yaitu menggunakan media MHA yang sebelumnya sudah dimasukkan $230 \mu \mathrm{l}$ suspensi bakteri $10^{\circ} \mathrm{CFU} / \mathrm{ml}$, tuangkan $20 \mathrm{ml}$ pada masing-masing cawan petri dan ratakan biarkan suspensi mengering. Masukkan kertas cakram yang telah diolesi sediaan salep dengan konsentrasi $5 \%, 10 \%$, $20 \%$, kontrol negatif yaitu salep tanpa ekstrak dan kontrol positif yaitu antibiotik 
klindamisin $1,2 \%$ kedalam cawan petri yang berisi media MHA yang telah memadat dan inkubasi pada suhu $37^{\circ} \mathrm{C}$ selama 48 jam. Amati zona bening yang terbentuk dan diukur menggunakan jangka sorong.

\section{HASIL DAN PEMBAHASAN}

\section{Determinasi Tanaman}

Hasil dari determinasi yang dilakukan di Herbarium Bogoriense, Bidang Botani Pusat Penelitian dan Pengembangan Biologi-LIPI Cibinong,menunjukkan bahwa daun pepaya (Carica papaya L.) yang diperoleh dari Desa Sodong Rt/Rw 002/003 Kecamatan Tigaraksa, Kabupaten Tangerang merupakan tumbuhan daun pepaya dengan nama latin Carica papaya L. dengan suku Caricaceae.

\section{Pembuatan Ekstrak Etanol 96\% Daun Pepaya (Carica papaya L)}

Serbuk simplisia yang diperoleh sebanyak 1000 gram kemudian dilakukan maserasi dengan menggunakan 10 liter pelarut etanol $96 \%$ selama 3 hari. Maserat yang diperoleh kemudian diuapkan pelarutnya menggunakan rotary evaporator pada suhu $50^{\circ} \mathrm{C}$. untuk memaksimalkan penguapan dilakukan pemanasan diatas waterbath dengan suhu $50^{\circ} \mathrm{C}$ hingga diperoleh ekstrak kental. Rendemen yang diperoleh dari hasil ekstraksi adalah sebesar $11,78 \%$.

Tabel 2. Hasil Ekstraksi Daun Pepaya (Carica papaya L.)

\begin{tabular}{lll}
\hline No & \multicolumn{1}{c}{ Jenis } & Hasil \\
\hline 1 & Daun Segar & $8000 \mathrm{~g}$ \\
2 & Daun Kering & $1400 \mathrm{~g}$ \\
3 & Serbuk & $1100 \mathrm{~g}$ \\
4 & Ekstrak Kental & $88,35 \mathrm{~g}$ \\
\hline
\end{tabular}

\section{Hasil Skrining Fitokimia}

Skrining fitokimia dilakukan untuk mendapatkan informasi awal dari suatu tanaman dari suatu tanaman mengenai golongan senyawa metabolit sekunder yang terdapat didalamnya, dalam hal ini adalah ingin memastikan kandungan kimia yang terdapat pada daun pepaya yang akan digunakan sebagai bahan untuk sediaan salep antijerawat agar khasiat yang diharapkan jelas terbukti. Berdasarkan hasil skrining fitokimia, senyawa-senyawa metabolit sekunder yang terkandung dalam ekstrak etanol 96\% daun pepaya (Carica papaya L.) dapat dilihat pada Tabel 3.

Tabel 3. Hasil Skrining Fitokimia Ekstrak Etanol 96\% Daun Pepaya

\begin{tabular}{lc}
\hline \multicolumn{1}{c}{ Metabolit Sekunder } & $\begin{array}{c}\text { Hasil } \\
\text { Pengujian }\end{array}$ \\
\hline Alkaloid & + \\
Saponin & - \\
Tanin & + \\
Flavonoid & + \\
Triterpenoid & + \\
Steroid & + \\
\hline
\end{tabular}

\section{Keterangan}

$(+)$ : terdapat metabolit sekunder

$(-) \quad$ : tidak terdapat metabolit sekunder

Hasil skrining fitokimia menujukkan bahwa ekstrak daun pepaya (Carica papaya L.) mengandung metabolit sekunder yaitu senyawa alkaloid, tanin, flavonoid, triterpenoid dan steroid.

\section{Parameter Mutu Simplisia}

Penetapan parameter standar simplisia bertujuan untuk mengetahui karakteristik bahan simplisia yang akan digunakan dan menjamin agar simplisia memenuhi persyaratan yang telah ditetapkan.

Tabel 4. Hasil Pengujian Parameter Mutu Simplisia

\begin{tabular}{llcc}
\hline No & Jenis & Hasil & Parameter \\
\hline 1 & Kadar air & $6,66 \%$ & $10 \%$ \\
2 & Kadar abu & $11,47 \%$ & $12 \%$ \\
3 & Susut & $6,87 \%$ & $10 \%$ \\
& pengeringan & & \\
\hline
\end{tabular}

Berdasarkan hasil pengujian mutu simplisia pada Tabel 4. Hal ini menunjukkan bahwa simplisia daun pepaya (Carica papaya L.) memenuhi parameter mutu simplisia.

\section{Uji Parameter Non Spesifik EKstrak}

Uji parameter non spesifik ekstrak dilakukan untuk mengetahui kemurnian dan ada tidaknya kontaminan dalam ekstrak daun pepaya. 
Tabel 5. Hasil Pengujian Non Spesifik Ekstrak

\begin{tabular}{|c|c|c|c|}
\hline No & Jenis & Hasil & Parameter \\
\hline 1 & Kadar air & $3,72 \%$ & $10 \%$ \\
\hline 2 & $\begin{array}{l}\text { Kadar } \\
\text { abu }\end{array}$ & $6,48 \%$ & $12 \%$ \\
\hline 3 & $\begin{array}{l}\text { Sisa } \\
\text { Pelarut }\end{array}$ & $0,08 \%$ & $1 \%$ \\
\hline
\end{tabular}

Berdasarkan hasil pengujian non spesifik ekstrak pada Tabel 5. Hal ini menunjukkan bahwa ekstrak yang diperoleh dapat digunakan sebagai bahan baku sediaan karena telah memenuhi parameter non spesifik ekstrak.

6. Hasil Formula Sediaan Salep Antijerawat Ekstrak Etanol 96\% Daun Pepaya (Carica papaya L.)

Pembuatan salep dilakukan dengan cara melarutkan nipagin kedalam PEG 400. Kemudian meleburkan PEG 4000 kedalam campuran 1 diaduk sampai dingin. Menambahkan ekstrak daun pepaya kedalam campuran 2 lalu diaduk sampai homogen. Menambahkan oleum citri sedikit dalam campuran 3. Salep disimpan dalam pot salep (Agung Nur dkk., 2018).

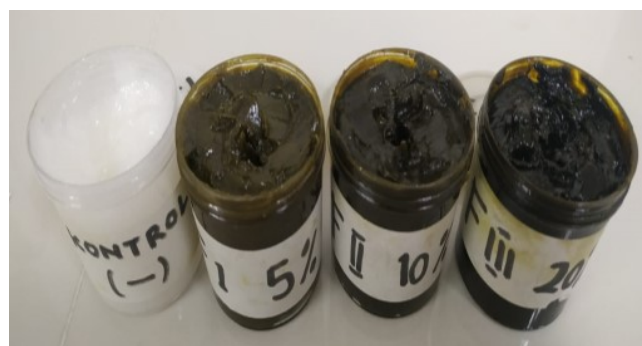

Gambar 1. Hasil Sediaan Salep Antijerawat Ekstrak Etanol 96\% Daun Pepaya

a) Evaluasi Fisik Sediaan Salep

Uji Organoleptis

Uji organoleptis bertujuan untuk mengetahui sifat fisik salep dan mengamati adanya perubahan bentuk, warna, dan bau yang terjadi selama penyimpanan.

Tabel 6. Pengamatan Uji Organoleptis

\begin{tabular}{|c|c|c|c|c|c|}
\hline \multirow[t]{2}{*}{ Pengamatan } & \multirow[t]{2}{*}{ Formula } & \multicolumn{4}{|c|}{$\begin{array}{l}\text { Pengamatan selama waktu penyimpanan Minggu } \\
\text { ke- }\end{array}$} \\
\hline & & 1 & 2 & 3 & 4 \\
\hline \multirow{5}{*}{ Warna } & $\mathrm{FI}$ & - & - & - & - \\
\hline & FII & - & - & - & - \\
\hline & & - & - & - & - \\
\hline & Kontrol Negatif & - & - & - & - \\
\hline & Kontrol Positif & - & - & - & - \\
\hline \multirow{5}{*}{ Bentuk } & $\mathrm{FI}$ & & & & \\
\hline & FII & - & - & - & - \\
\hline & FIII & - & - & - & - \\
\hline & Kontrol Negatif & - & - & - & - \\
\hline & Kontrol Positif & - & $\begin{array}{l}- \\
-\end{array}$ & $\begin{array}{l}- \\
-\end{array}$ & - \\
\hline \multirow{5}{*}{ Bau } & $\mathrm{FI}$ & - & - & - & - \\
\hline & FII & - & - & - & - \\
\hline & FIII & - & - & - & - \\
\hline & Kontrol Negatif & - & - & - & - \\
\hline & Kontrol Positif & - & - & - & - \\
\hline
\end{tabular}

Keterangan :

$(-)$ : Tidak terjadi perubahan

$(+)$ : Terjadi perubahan

Berdasarkan hasil pada Tabel 6 diatas, hasil pengamatan organoleptis sediaan salep dengan berbagai konsentrasi memiliki stabilitas warna, bentuk dan bau yang stabil. Hal ini dikarenakan zat aktif dan basis salep tercampur dengan sempurna.

\section{Uji Homogenitas}

Uji homogenitas bertujuan untuk melihat dan mengetahui bahan-bahan sediaan salep tercampur dengan merata atau tidak. 
Tabel 7. Hasil Uji Homogenitas Salep Antijerawat Ekstrak Etanol 96\% Daun Pepaya

\begin{tabular}{lcccc}
\hline \multirow{2}{*}{ Formula } & \multicolumn{3}{c}{ Waktu Penyimpanan Minggu Ke- } \\
\cline { 2 - 5 } & $\mathbf{1}$ & $\mathbf{2}$ & $\mathbf{3}$ & $\mathbf{4}$ \\
\hline FI & Homogen & Homogen & Homogen & Homogen \\
FII & Homogen & Homogen & Homogen & Homogen \\
FIII & Homogen & Homogen & Homogen & Homogen \\
Kontrol negatif & Homogen & Homogen & Homogen & Homogen \\
Kontrol positif & Homogen & Homogen & Homogen & Homogen \\
\hline
\end{tabular}

Keterangan :

FI

FII

FIII

Kontrol negatif

Kontrol positif

: Formula dengan konsentrasi ekstrak daun pepaya $5 \%$

: Formula dengan konsentrasi ekstrak daun pepaya $10 \%$

: Formula dengan konsentrasi ekstrak daun pepaya $20 \%$

: Formula tanpa ekstrak daun pepaya

: Gel Clindamycin 1,2\%

\section{Uji pH}

Uji $\mathrm{pH}$ bertujuan untuk mengetahui berapa nilai $\mathrm{pH}$ yang terdapat pada sediaan.Nilai $\mathrm{pH}$ tidak boleh terlalu asam karena dapat mengiritasi kulit dan tidak boleh terlalu basa karena dapat membuat kulit bersisik (Yulistia B dkk., 2016).

Tabel 8. Hasil Uji pH Salep Antijerawat Ekstrak Etanol 96\% Daun Pepaya

\begin{tabular}{lcccc}
\hline \multirow{2}{*}{ Formula } & \multicolumn{4}{c}{ Pengujian } \\
\cline { 2 - 5 } \multicolumn{1}{c}{$\mathbf{1}$} & $\mathbf{2}$ & $\mathbf{3}$ & $\mathbf{4}$ \\
\hline FI & 6 & 6 & 6 & 6 \\
FII & 6 & 6 & 6 & 6 \\
FIII & 6 & 6 & 6 & 6 \\
Kontrol negatif & 6 & 6 & 6 & 6 \\
Kontrol positif & 5 & 5 & 5 & 5 \\
\hline
\end{tabular}

Keterangan :

FI : Formula dengan konsentrasi ekstrak daun pepaya $5 \%$

FII : Formula dengan konsentrasi ekstrak daun pepaya $10 \%$

FIII : Formula dengan konsentrasi ekstrak daun pepaya $20 \%$

Kontrol Negatif : Formula tanpa ekstrak etanol 96\% daun pepaya

Kontrol positif : Gel Clindamycin 1,2\%

Berdasarkan hasil pada tabel 8 diatas, hasil uji $\mathrm{pH}$ semua formula memasuki persyaratan ). Berdasarkan rentang $\mathrm{pH}$ kulit normal yaitu 4,56,5 dan Standar Nasional Indonesia (SNI) 164399-1996 Mengenai mutu sediaan pelembab pada kulit yaitu $\mathrm{pH} 4,5-8$.

\section{Uji Viskositas}

Pengujian viskositas berfungsi untuk mengetahui viskositas (kekentalan) salep. Viskositas merupakan parameter yang menggambarkan tentang besarnya tahanan suatu cairan untuk mengalir. Semakin besar tahannya, maka viskositas juga semakin besar (Yulistia B dkk., 2016).

Tabel 9. Hasil Uji Viskositas Pengujian Minggu ke-

\begin{tabular}{lcccc} 
& \multicolumn{4}{c}{$\begin{array}{c}\text { Pengujian Minggu ke- } \\
\text { (Cps) }\end{array}$} \\
\cline { 2 - 5 } & $\mathbf{1}$ & $\mathbf{2}$ & $\mathbf{3}$ & $\mathbf{4}$ \\
\hline FI & 44014 & 43951 & 42195 & 41351 \\
FII & 39585 & 38789 & 37224 & 36057 \\
FIII & 37299 & 36319 & 35247 & 33283 \\
Kontrol & 34842 & 33488 & 32688 & 31024 \\
Negatif & & & & \\
Kontrol & 1313 & 1287 & 1198 & 1048 \\
Positif & & & & \\
\hline
\end{tabular}

Keterangan :

FI : Formula dengan konsentrasi ekstrak daun pepaya $5 \%$

FII : Formula dengan konsentrasi ekstrak daun pepaya $10 \%$

FIII : Formula dengan konsentrasi ekstrak daun pepaya $20 \%$

Kontrol negatif : Formula tanpa ekstrak etanol $96 \%$ daun pepaya

Kontrol positif : Gel Clindamycin 1,2\%

Berdasarkan hasil pengujian viskositas pada Tabel 9 dapat dilihat bahwa sediaan salep ekstrak etanol $96 \%$ daun pepaya yaitu terjadinya penurunan nilai viskositas pada semua formula setiap minggunya. Berdasarkan syarat mutu sediaan kulit menurut Standar Nasional Indonesia (SNI) 1995 nilai viskositas untuk sediaan kulit yaitu 2000-50000 CPs, maka semua formula sediaan salep telah memenuhi syarat. 


\section{Uji Daya Sebar}

Pengujian daya sebar salep bertujuan untuk mengetahui luas sebaran sediaan salep yang dibuat, semakin besar daya sebar semakin bagus sediaannya.

Tabel 10. Hasil Uji Daya Sebar Salep Antijerawat Ekstrak Etanol 96\% Daun Pepaya

\begin{tabular}{clcccc}
\hline $\begin{array}{c}\text { Berat } \\
\text { Beban }\end{array}$ & \multirow{2}{*}{ Formula } & \multicolumn{4}{c}{ Luas (Cm) Minggu ke- } \\
\cline { 2 - 6 } & & $\mathbf{1}$ & $\mathbf{2}$ & $\mathbf{3}$ & $\mathbf{4}$ \\
\hline \multirow{6}{*}{$200 \mathrm{~g}$} & FI & 5,1 & 5,2 & 5,4 & 5,5 \\
& Fll & 5,3 & 5,4 & 5,6 & 5,8 \\
& FIII & 5,3 & 5,5 & 5,7 & 6 \\
& Kontrol & 5 & 5 & 5,2 & 5,3 \\
& Negatif & & & & \\
& Kontrol & 5,7 & 6 & 6,1 & 6,1 \\
& Positif & & & & \\
\hline
\end{tabular}

Keterangan :

FI : Formula dengan konsentrasi ekstrak daun pepaya $5 \%$

FII : Formula dengan konsentrasi ekstrak daun pepaya $10 \%$
FIII : Formula dengan konsentrasi ekstrak daun pepaya $20 \%$

Kontrol Negatif : Formula tanpa ekstrak etanol $96 \%$ daun pepaya

Kontrol Positif : Gel Clindamycin 1,2\%

Berdasarkan hasil pada Tabel 10 diatas, daya sebar sediaan salep antijerawat ekstrak etanol $96 \%$ daun pepaya setiap minggunya semakin meningkat dan semakin tinggi konsentrasi ekstrak daun pepaya maka daya sebar sediaan salep tersebut semakin meningkat (Yulistia B dkk., 2016). Berdasarkan persyaratan daya sebar untuk sediaan topikal yaitu sekitar 5-7 cm (Ulaen dkk., 2012).

\section{Uji daya lekat}

Pengujian daya lekat bertujuan untuk mengetahui waktu yang dibutuhkan oleh salep untuk melekat di kulit. Semakin lama daya lekat salep melekat antara salep dengan kulit maka semakin baik sehingga absorbsi obat oleh kulit akan semakin baik.

Tabel 11. Hasil Uji Daya Lekat Salep Antijerawat Ekstrak Etanol 96\% daun Pepaya

\begin{tabular}{lclcc}
\hline \multirow{2}{*}{ Formula } & \multicolumn{4}{c}{ Durasi Daya Lekat (menit/detik) Minggu ke- } \\
\cline { 2 - 5 } & \multicolumn{1}{c}{$\mathbf{1}$} & $\mathbf{2}$ & $\mathbf{3}$ & $\mathbf{4}$ \\
\hline FI & 2 menit 10 detik & 2 menit 7 detik & 2 menit 2 detik & 1 menit 51 detik \\
FII & 2 menit 27 detik & 2 menit 20 detik & 2 menit 9 detik & 1 menit 42 detik \\
FIII & 2 menit 50 detik & 2 menit 50 detik & 2 menit 30 detik & 1 menit 38 detik \\
Kontrol Negatif & 2 menit 2 detik & 1 menit 50 detik & 1 menit 50 detik & 1 menit 24 detik \\
Kontrol Positif & 1 menit 6 detik & 1 menit 6 detik & 1 menit 1 detik & 58 detik \\
\hline
\end{tabular}
Keterangan :
FI : Formula dengan konsentrasi ekstrak daun pepaya $5 \%$
FII : Formula dengan konsentrasi ekstrak daun pepaya $10 \%$
FIII : Formula dengan konsentrasi ekstrak daun pepaya $20 \%$
Kontrol Negatif : Formula tanpa ekstrak etanol $96 \%$ daun pepaya
Kontrol Positif : Gel Clindamycin 1,2

Berdasarkan hasil pengujian menunjukkan bahwa daya lekat sediaan salep semua formula dengan durasi penyimpanan selama 4 minggu telah memenuhi persyaratan. Adapun syarat waktu daya lekat yang baik adalah tidak kurang dari 4 detik (Ulaen dkk., 2012).

\section{b) Pengujian sediaan salep terhadap bakteri Propionibacterium acnes}

Uji aktivitas salep antijerawat ekstrak etanol $96 \%$ daun pepaya sebagai antibakteri terhadap bakteri Propionibacterium acnes dilakukan di Laboratorium Mikrobiologi Balai Pengkajian Bioteknologi (BPPT) Pusat
Penelitian Ilmu Pengetahuan dan Teknologi (Puspitek), Serpong.

Sebelum dilakukan uji aktivitas antibakteri secara steril, terlebih dahulu dilakukan persiapan dan sterilisasi alat-alat uji ke dalam autoklaf pada suhu $121^{\circ} \mathrm{C}$ selama 15 menit, bertujuan untuk memperkecil kontaminan yang menempel pada alat yang akan digunakan dalam pengujian.

Selanjutnya yaitu jumlah koloni bakteri Propionibacterium acnes adalah 2,6 x 10 . Media yang digunakan dalam pengujian ini yaitu menggunakan media Mueller Hinton Agar (MHA). Pembuatan media MHA yaitu dengan menggunakan 2,28 g serbuk MHA 
pada $60 \mathrm{ml}$ aquadest untuk tiga cawan petri, masing-masing cawan $20 \mathrm{ml}$ dan kemudian disuspensikan bakteri sebanyak $230 \mu \mathrm{l}$. Kemudian selanjutnya diinkubasi dengan suhu $37^{\circ} \mathrm{C}$ selama 48 jam.

Tabel 12. Hasil Uji Bakteri Propionibacterium acnes

\begin{tabular}{lccc}
\multicolumn{4}{c}{ acnes } \\
\hline \multirow{3}{*}{ Konsentrasi Uji } & \multicolumn{3}{c}{$\begin{array}{c}\text { Zona Bening Salep } \\
\text { Ekstrak Etanol 96\% Daun } \\
\text { Pepaya (mm) }\end{array}$} \\
\cline { 2 - 4 } & I & II & III \\
\hline FI & 6,00 & 6,00 & 6,00 \\
FII & 6,00 & 6,00 & 6,00 \\
FIII & 6,00 & 6,00 & 6,00 \\
Kontrol Positif & 20,43 & 22,72 & 20,18 \\
(clindamycin & & & \\
$\begin{array}{l}1,2 \%) \\
\text { Kontrol Negatif } \\
\text { (Salep tanpa }\end{array}$ & 6,00 & 6,00 & 6,00 \\
Ekstrak) & & & \\
\hline
\end{tabular}

Keterangan :

FI : Formula dengan konsentrasi ekstrak daun pepaya $5 \%$

FII : Formula dengan konsentrasi ekstrak daun pepaya $10 \%$

FIII : Formula dengan konsentrasi ekstrak daun pepaya $20 \%$

Kontrol negatif: Formula tanpa ekstrak etanol 96\% daun pepaya

Kontrol positif : Gel Clindamycin 1,2\%

Berdasarkan tabel 12 dapat dilihat bahwa hasil pengujian antibakteri sediaan salep antijerawat ekstrak etanol $96 \%$ daun pepaya terhadap bakteri Propionibacterium acnes dengan variasi konsentrasi $5 \%, 10 \%$, $20 \%$ dan kontrol negatif tidak menunjukkan adanya efektivitas antibakteri. Hal ini disebabkan karena rendahnya konsentrasi ekstrak daun pepaya yang digunakan sebagai zat akif dalam sediaan salep. Kemudian untuk kontrol positif clindamycin $1,2 \%$ terbentuknya zona bening atau adanya daya hambat terhadap pertumbuhan bakteri yaitu dengan rata-rata $21,11 \mathrm{~mm}$.

Dari hasil tersebut dapat diketahui bahwa sediaan salep ekstrak daun pepaya dengan konsentrasi 5\%,10\% dan 20\% tidak menghasilkan zona hambat pertumbuhan bakteri Propionibacterium acne. Hasil ini berbanding terbalik dengan pengujian yang dilakukan oleh Fitria (2015) yang menggunakan ekstrak daun pepaya terhadap daya hambat pertumbuhan bakteri Propionibacterium acne yaitu dengan konsentrasi $5 \%$ mampu menghambat pertumbuhan bakteri dengan zona hambat $13 \mathrm{~mm}, 10 \%$ dengan zona hambat $15 \mathrm{~mm}$ dan konsentrasi tertinggi pada $20 \%$ mampu menghambat bakteri Propionibacterium acne dengan zona hambat paling optimal yaitu sebesar $19 \mathrm{~mm}$.

Hal ini diduga karena jumlah dari kandungan senyawa metabolit sekunder yang telah disebutkan hasilnya pada tabel 3 tidak kuat untuk menghambat pertumbuhan bakteri Propionibacterium acnes. Skrining fitokimia yang dilakukan pada penelitian ini hanya membuktikan adanya suatu senyawa metabolit sekunder secara kualitatif, tidak secara kuantitatif. Selain itu, faktor lain seperti suhu, kelembaban, $\mathrm{pH}$, kandungan unsur hara didalam tanah dan ketinggian tempat. (Katuuk, Rino H.H dkk., 2018). Hal itulah yang menyebabkan perbedaan dalam penghambatan bakteri Propionibacterium acnes.

\section{KESIMPULAN}

Berdasarkan hasil penelitian dapat disimpulkan bahwa Ekstrak etanol 96\% daun pepaya (Carica papaya L.) dapat diformulasikan menjadi sediaan salep antijerawat dengan variasi konsentrasi $\mathrm{FI} 5 \%$, FII 10\% dan FIII 20\% dan memiliki karakteristik fisik yang baik meliputi (Organoleptis, homogenitas, $\mathrm{pH}$, viskositas, daya sebar dan daya lekat). Akan tetapi tidak memberikan hambatan terhadap pertumbuhan bakteri Propionibacterium acnes.

\section{SARAN}

Perlu dilakukan penelitian lebih lanjut dengan pengembangan metode baru untuk mempermudah dalam proses penelitian dan penerapan.

\section{DAFTAR PUSTAKA}

Agung N.C., Yuliana, Nilla A. 2018. Uji Aktivitas Salep Antijerawat Ekstrak Etanol Daun Binahong (Anredera cordifolia(Ten) Steenis) Terhadap Bakteri Propionibacterium acne. Jurnal Para Pemikir. Sekolah Tinggi Kesehatan Bhakti Mandala Husada Slawi.

Handayani, S., Wirasutisna, K. R., \& Insanu, M. 2017. Penapisan Fitokimia dan Karakterisasi Simplisia Daun Jambu Mawar (Syzygium Jambos Alston). JF Fik UINAM, 5(3), 174-183. 
Katuuk, Rino H.H., Wanget S.A., dan Tumewu Pemmy. 2018. Pengaruh Perbedan Ketinggian Terhadap Kandungan Metabolit Sekunder Pada Gulma Babadotan (Ageratum conyzoides L.). Fakultas Pertanian Universitas Sam Ratulangi Manado.

Naibaho, D.H., Yamkan, V,Y., Weni, Wiyono,. 2013. Pengaruh Basis Salep Ekstrak Daun Kemangi (Ocinum sanchum L.) pada Kulit Punggung Kelinci yang dibuat Infeksi staphylococcus aureus. Jurnal ilmiah Farmasi - UNSRAT.

Peristiowati, Yuli., Puspitasari, Yuni. 2018. Potensi Daun Pepaya. Sidoarjo: Indonesia Pustaka.
Sawarkar, H.A, Khadabadi, S.S., Mankar, D.M., farooqui, I.A., Jagtap, N.S., 2010. Biological Evaluation Of Herbal Anti acne Gel. International Journal Of PharmTech Research, Vol 2, No 3.

Ulaen, Selfie P.J., Banne, Yos Suatan dan Ririn A. 2012. Pembuatan Salep Antijerawat dari Ekstrak Rimpang Temulawak (Curcuma xanthorrhiza Roxb). Jurnal IImiah Farmasi, 3(2):45-49.

Yulistia B. S., Tri Astuti., Nur. R. 2016. Formulasi Sediaan Salep Ekstrak Etanol Daun Alpukat (Persea Americana Mill.) Sebagai Antiacne. Jurnal. Akademi Farmasi. Samarinda. 